\title{
Cytotoxic Effects of Some N-Substituted-2-Amino-1H-Benzimidazoles
}

\section{Mavrova AT ${ }^{1}$, Wesselinova $\mathrm{D}^{2 *}$, Tsenov $\mathrm{JA}^{3}$ and Denkova $\mathrm{P}^{3}$}

${ }^{1}$ University of Chemical Technology and Metallurgy, 8Kliment Ohridski Blvd., 1756 Sofia, Bulgaria

${ }^{2}$ Institute of Parasitology and Experimental Pathology, Bulgarian Academy of Science, 1113 Sofia, Bulgaria

${ }^{3}$ Institute of Organic Chemistry, Bulgarian Academy of Science, 1113 Sofia, Bulgaria

\begin{abstract}
The cytotoxic activity of previously synthesized (benzimidazol-2-yl) amines were evaluated on two cancer cellines: human epithelial colorectal carcinoma HT-29 (American Type Culture Collection HTB-38), breast cancer cells with epithelial-like morphology MDA-MB 231 (American Type Culture Collection ATCC HTB-26), and on normal spleen cells as well as. Indicative cytotoxic activity was ascertained for $\mathrm{N}-1 \mathrm{H}$-benzimidazol-2-yl-1-propyl-1H-benzimidazol2-amine 15, 1-propyl-N-(1-propyl-1 H-benzimidazol-2-yl)-1H-benzimidazol-2-amine 21 and 1-methyl-N-(1-propyl-1Hbenzimidazol-2-yl)-1H-benzimidazol-2-amine18 against the cellular line HT-29. The estimated IC ${ }_{50}$ values were 0.91 , 1.92 and $1.98 \mu \mathrm{M}$ respectively. The same compounds exhibited comparatively high antiproliferative activity against MDA-MB-231 cells. The realized $I_{50}$ values were in the range $0.006-1.48 \mu \mathrm{M}$. Compounds 14, 16, 17, 18 and 21revealed stimulating activity to the normal spleen cells, where the $\mathrm{EC}_{50}$ values were between $0.5 \times 10^{-4} \mu \mathrm{M}$ for compound 21 and $0.013 \mu \mathrm{M}$ for compound 14 .
\end{abstract}

Keywords: 2-aminobenzimidazoles; Bis (benzimidazol-2-yl) amines; Synthesis; Cytotoxicity; Proliferative effect; HT-29; MDA-MB231-cell lines

\section{Introduction}

The 2-aminobenzimidazole represents a building block in the structure of several medicinally relevant small molecules. Therefore, the wide spectrum of biological activities (immunotropic, diuretic, anti histaminic, anti-inflammatory, antiviral) associated with the benzimidazolesis of great interest [1-6].The availability of the 2-aminobenzimidazolemoietyinthestructureofmanyantihelmithicand antiparasitic drugs support further the importance of the benzimidazole ring system in the development of new and better chemotherapeutical agents [7-11]. Nowadays many 2-aminobenzimidazole derivatives, which are known as microtubule inhibitors were evaluated for their anticancer activity and are appropriate as primary substances for the synthesis of novel anticancer drugs. It was established that benomyl and colchicine synergistically inhibits cell proliferation and mitosis of human cervical cancer (HeLa) cell line [12] while carbendazim inhibits proliferation of human cancer cells, including drug- and multidrugresistant and p53-deficient cell lines [13]. Some albendazole derivatives demonstrated cytotoxic activity up to ten times higher than the parent drug (albendazole) against the HT-29-cell line and the definite prostate cancer cell line (PC-3). On the other hand many used in the praxis antiparasitic 2-aminobezimidazole derivatives revealed cytotoxicity against some leukemic and myeloma cells like SW707 (rectal), HCV29T (bladder), A549 (lung) and T47D (breast cancer) [14-18].

In the view of the above mentioned facts and as a continuation of our research in the field of benzimidazoles we undertook investigations on the effects of some bis (benzimidazol-2-yl) amines on human epithelial colorectal carcinoma HT-29, breast cancer cells, epitheliallike morphology MDA-MB 231 and normal spleen cells. Because of the structural similarity of benzimidazole nucleus to the purine basesof the DNA, we supposed that the benzimidazole derivatives would facile collaborate with biological substances. It could be anticipated that the incorporating of a second benzimidazole ring in the 2-aminobenzimidazole molecule can enhanced not only antiparasitic efficacy but can also lead to the appearance of proliferative or cytotoxic properties of the studied compounds. To find out appropriate medicines that would have specificity to cancer cells is indisputable.

\section{Materials and Methods}

\section{Chemistry}

The compounds 1-21 (Scheme 1) were synthesized as previously reported [11]. The tested compounds 13-21 were obtained by the reaction of the corresponding benzimidazole-2-sulfonic acids and appropriate benzimidazole-2-amines at $180^{\circ} \mathrm{C}$ for 30 minutes. After

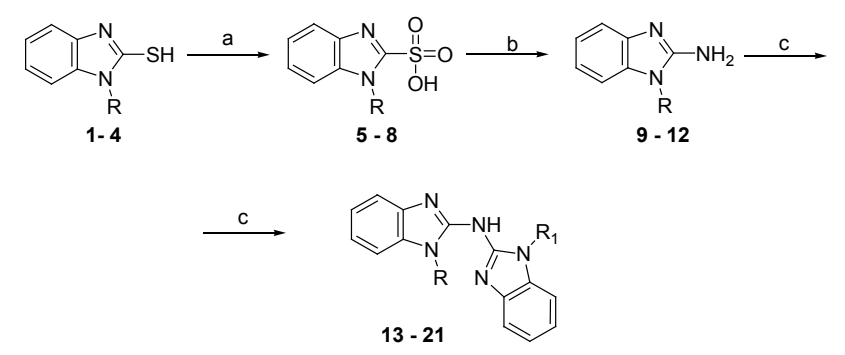

13: $\mathrm{R}=\mathrm{H}, \mathrm{R}_{1}=\mathrm{CH}_{3} ; 14: \mathrm{R}=\mathrm{H}, \mathrm{R}_{1}=\mathrm{C}_{2} \mathrm{H}_{5} ; 15: \mathrm{R}=\mathrm{H}, \mathrm{R}_{1}=\mathrm{C}_{3} \mathrm{H}_{7}$;

16: $\mathrm{R}=\mathrm{CH}_{3} \cdot \mathrm{R}_{1}=\mathrm{CH}_{3} ; 17: \mathrm{R}=\mathrm{CH}_{3} \mathrm{R}_{1}=\mathrm{C}_{2} \mathrm{H}_{5}:$ 19: $\mathrm{R}=\mathrm{C}_{2} \mathrm{H}_{5}, \mathrm{R}_{1}=\mathrm{C}_{2} \mathrm{H}_{5} ; 20: \mathrm{R}=\mathrm{C}_{2} \mathrm{H}_{5}, \mathrm{R}_{1}=\mathrm{C}_{3} \mathrm{H}_{7} ; 21: \mathrm{R}=\mathrm{C}_{3} \mathrm{H}_{7}, \mathrm{R}_{1}=\mathrm{C}_{3} \mathrm{H}_{7}$;

Scheme 1: Synthesis of bis(benzimidazol-2-yl)amines; Regents andconditions:

a) $\mathrm{KMnO}_{4}, 25 \% \mathrm{NaOH}$, reflux; b) $25 \% \mathrm{NH}_{4} \mathrm{OH}, 145^{\circ} \mathrm{C}$, in welded ampoule; c) heating with 1 -(un)substituted-1 $\mathrm{H}$-benzimidazol-2-sulphonic acid at $180^{\circ} \mathrm{C}$

*Corresponding author: Diana Wesselinova, Institute of Parasitology and Experimental Pathology, Bulgarian Academy of Science, 1113 Sofia, Bulgaria, E-mail: dianaw33@hotmail.com

Received May 10, 2012; Accepted May 24, 2012; Published May 26, 2012

Citation: Mavrova AT, Wesselinova D, Tsenov JA, Denkova P (2012) Cytotoxic Effects of Some N-Substituted-2-Amino-1H-Benzimidazoles. J Bioequiv Availab 4 052-055. doi:10.4172/jbb.1000112

Copyright: (c) 2012 Mavrova AT, et al. This is an open-access article distributed under the terms of the Creative Commons Attribution License, which permits unrestricted use, distribution, and reproduction in any medium, provided the original author and source are credited. 
cooling the fusion was diluted with ethanol. The filtered pellet was recrystallized with ethanol.

\section{MTS test}

The cells, incubated with the substances [19] were tested for proliferation ability by the MTS assay described in the protocol of "Promega" [20]. Percentage of untreated control cells (100\% viability), was calculated for each concentration. In the controls the calculated data, received after incubation of each cell kind only with DMSO [19]. All data points represent an average of three independent assays.

\section{Statistics}

After the Student's test the statistical errors were $\mathrm{p} \leq 0.05$.

$\mathrm{EC}_{50}$ and $\mathrm{IC}_{50}$ were calculated with the "Origin" computer program.

\section{Result and Discussion}

The synthesis of the studied compounds was accomplished as outlined in Scheme 1. The reaction of 1,2-diaminobenzene, carbon disulfide and sodium hydroxide in ethanol medium yielded 1H-benzimidazol-2-thiol $\mathbf{1}$. The fusion of 1-alkyl-benzimidazoles with sulfur at $180^{\circ} \mathrm{C}$ yielded in 1-alkyl-benzimidazole-2-thiols 2-4. The oxidation of the 1-(un)substituted- $1 H$-benzimidazol-2-yl-tiols 1-4 with $\mathrm{KMnO}_{4}$ in $25 \%$ water solution of sodium hydroxide led to the formation of 1- (un) substituted-1H-benzimidazol-2-yl-sulfonic acids. The reaction of benzimidazol-2-yl-sulfonic acids 5-8, carried out with 25\% ammonium hydroxide resulted in 2-aminobenzimidazoles 9-12. The bis (benzimidazol-2-yl) amines 13-21 were synthesized by heating benzimidazol-2-yl-sulfonic acids 5-8 and 2-aminobenzimidazoles 9-12 at $180^{\circ} \mathrm{C}$.

Compounds 13-21 were evaluated for their anti proliferative effect on human colorectal cancer cell lineHT-29, breast cancer cells MDAMB-231 and normal spleen cells using the MTS test [20].

The conversation of the MTS tetrazolium compound into blue colored formazan is due to NADPH or NADH from the examined cells [21].

The bis (benzimidazol-2-yl) amines 13-21 were DMSO-dissolved at a concentration of $500 \mathrm{ml}$. The stock solution was diluted further 10, 100, 1000 and10000 times. Untreated cells, cultured only in culture medium were the controls. After $24 \mathrm{~h}$ of incubation the samples were used in the MTS assay for cell survival and proliferation. All results are given in Figures 1,2 and 3. The calculated and plotted result and the values of $\mathrm{IC}_{50}$ and $\mathrm{EC}_{50}$ are represented in Table1.

From all tested substances compounds 15, 18 and 21 expressed toxic effect against HT-29 cells. The unsubstituted at 1-th position in the one of the two benzimidazole rings compound 15 showed the most pronounced toxic effect to HT-29 cells, $\mathrm{IC}_{50}=0.91 \mu \mathrm{M}$, followed by the compound $\mathbf{2 1}, \mathrm{IC}_{50}=1,92 \mu \mathrm{M}$ and $\mathbf{1 8}-\mathrm{IC}_{50}=1,98$ $\mu \mathrm{M}$. Compounds 15, 18, 19, 20 and 21 exhibited relatively high anti proliferative activity to MDA-MB-231 cells. Most toxic were 1-propylN-(1-propyl-1H-benzimidazol-2-yl)-1H-benzimidazol-2-amine 21 and N-1H-benzimidazol-2-yl-1-propyl-1H-benzimidazol-2-amine 15 with $\mathrm{IC}_{50}-0.0006 \mu \mathrm{M}$ and $\mathrm{IC}_{50}-0.135 \mu \mathrm{M}$ respectively.

From the results, given in Table 1, it can be seen that compounds $14,16,17,18$ and 21 showed definitely stimulating effects to the normal

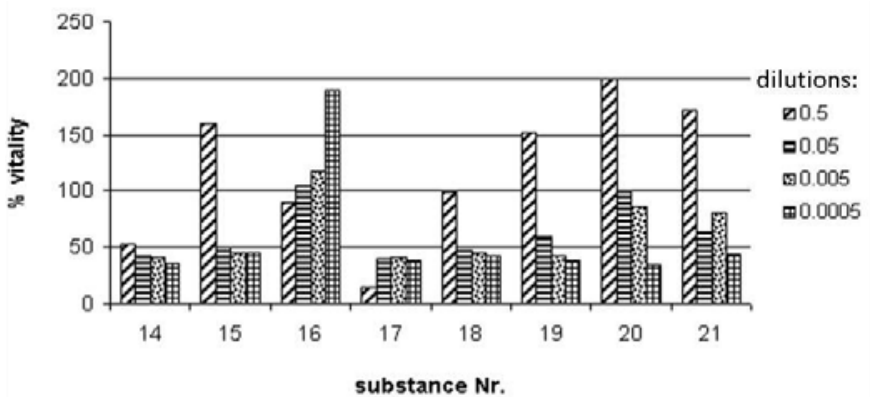

Figure 1: HT-29 cells vitality (\%)

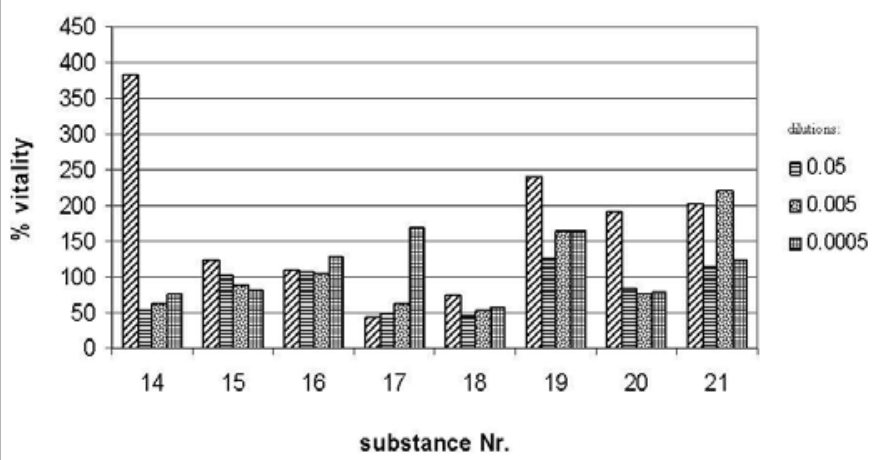

Figure 2: MDA-MB-231 cells vitality (\%)

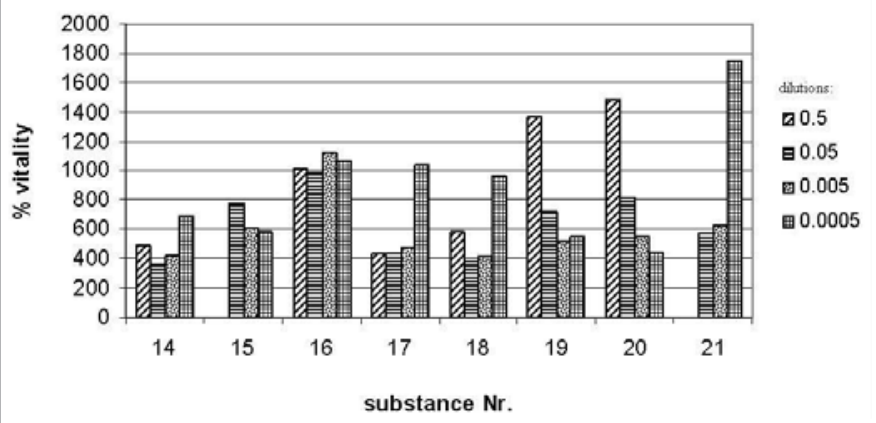

Figure 3: Normal spleen cells vitality (\%).

spleen cells. The $\mathrm{EC}_{50}$ data varied from $0.05 \times 10^{-3} \mu \mathrm{M}$ for 1-propyl-N(1-propyl-1H-benzimidazol-2-yl)-1H-benzimidazol-2-amine 21 to $0.013 \mu \mathrm{M}$ for $\mathrm{N}$-1H-benzimidazol-2-yl-1-ethyl-1H-benzimidazol2 -amine 14. If the result for compound 21 is taken in mind it must be emphasized that 1-propyl-N-(1-propyl-1H-benzimidazol-2-yl)$1 \mathrm{H}$-benzimidazol-2-amine exhibit proliferative effect to the normal spleen cells even at higher dilutions in comparison to this at which the compound displays cytotoxic effect on HT-29 cells and MDAMB-231 cells. As far as the properties of 1-methyl-N-(1-propyl-1Hbenzimidazol-2-yl)-1H-benzimidazol-2-amine 18 should be pointed out that this compound possessed a relative high cytotoxicity both to HT-29 cells $\left(\mathrm{IC}_{50}=1.9 \mu \mathrm{M}\right)$ and to MDA-MB-231 $\left(\mathrm{IC}_{50}=1.4 \mu \mathrm{M}\right)$ cell line, but against normal spleen cells the same compound displayed proliferative activity at lower concentration $\left(\mathrm{EC}_{50}=0.004 \mu \mathrm{M}\right)$. The last result is important showing the selective capacity of substance 18. Surprising results demonstrated N-1H-benzimidazol-2-yl-1- 
Citation: Mavrova AT, Wesselinova D, Tsenov JA, Denkova P (2012) Cytotoxic Effects of Some N-Substituted-2-Amino-1H-Benzimidazoles. J Bioequiv Availab 4: 052-055. doi:10.4172/jbb.1000112

\begin{tabular}{|c|c|c|c|c|c|c|}
\hline \multirow[t]{2}{*}{ Compound } & \multicolumn{3}{|c|}{$\mathrm{IC}_{50} \pm \mathrm{SE}(\mu \mathrm{M})$} & \multicolumn{3}{|c|}{$\mathrm{EC}_{50} \pm \mathrm{SE}(\mu \mathrm{M})$} \\
\hline & HT-29 & MDA-MB-231 & Normal spleen cells & HT-29 & MDA-MB-231 & Normal spleen cells \\
\hline 14 & $3.5 .10^{3} \pm 0.35$ & $1,65 \pm 0.07$ & - & - & - & $0.013 \pm 0.07$ \\
\hline 15 & $0.91 \pm 0.11$ & $0.135 \pm 0.06$ & $0.11 \pm 0.62$ & - & - & - \\
\hline 16 & - & - & - & $0.01 \pm 0.046$ & $0.002 \pm 0.05$ & $0.047 \pm 0.32$ \\
\hline 17 & - & - & - & $0.48 \pm 0.009$ & $1.48 \pm 0.3$ & $0.005 \pm 0.15$ \\
\hline 18 & $1.98 \pm 0.43$ & $1.48 \pm 0.06$ & - & - & - & $0.004 \pm 0.13$ \\
\hline 19 & - & $1.87 \pm 0.24$ & $0.23 \pm 1.96$ & $0.005 \pm 0.38$ & - & - \\
\hline 20 & $7.10^{3} \pm 0.05$ & $16.7 \pm 0.28$ & $1.67 \pm 0.02$ & - & - & - \\
\hline 21 & $1.92 \pm 0.08$ & $0.006 \pm 0.27$ & - & - & - & $0.5 .10^{-4} \pm 0.6$ \\
\hline
\end{tabular}

Table 1: In vitro cytotoxicity and proliferative effects on HT-29, MDA-MB-231and normal spleen cells.

ethyl-1H-benzimidazol-2-amine $\mathbf{1 4}$ revealing to be almost non-toxic to HT-29 and toxic to MDA-MB-231, but possessing a proliferative effect on normal spleen cells at a lower concentration $\left(\mathrm{EC}_{50}-0.013\right.$ $\mu \mathrm{M})$. Proliferative influence on all the experimental cells manifested 1-methyl-N-(1-methyl-1H-benzimidazol-2-yl)-1H-benzimidazol2-amine 16 and 1-ethyl-N-(1-methyl-1H-benzimidazol-2-yl)-1Hbenzimidazol-2-amine 17.

The significant statistical deviations in all examinations were determined ( $\mathrm{p} \leq 0.05)$.

\section{Conclusion}

The preliminary screening in vitro showed that the studied compounds 15, N-1H-benzimidazol-2-yl-1-propyl-1H-benzimidazol2-amine 18 and 1-propyl-N-(1-propyl-1H-benzimidazol-2-yl)-1Hbenzimidazol-2-amine 21 possessed comparatively high cytotoxic effect on HT-29 cells. IC $_{50}$ values were in the range 0.91-1.98 $\mu \mathrm{M}$. Strongest anti proliferative effect on MDA-MB-231 cells had compounds 15 and 21 with $\mathrm{IC}_{50}-0.0006 \mu \mathrm{M}$ and $\mathrm{IC}_{50}-0.135 \mu \mathrm{M}$ respectively.

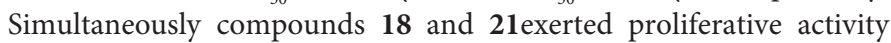
to the normal spleen cells. On the base of these promising screening results, it may be concluded that the selectivity of compounds $\mathbf{1 8}$ and 21 will be essential for anticancer drug development.The received experimental data substantiate the hypothesis that the introduction of another benzimidazole ring at $2^{\text {nd }}$ position in the structure of 2 -aminobenzimidazole as well as the presence of a butyl group at $1^{\text {st }}$ place are favorable to the reciprocal action of these molecules with thebiological agents.

\section{Acknowledgments}

The financial support by the National Research Fund of Bulgaria for the purchase of Bruker Avance II+ 600 NMR spectrometer in the framework of the Program"Promotion of the Research Potential through Unique Scientific Equipment" (Project UNA-17/2005) is gratefully acknowledged.

\section{References}

1. Nawrocka W, Zimecki M (1998) Synthesis and immunotropic activity of some 2-aminobenzimidazoles, part 4. Arch Pharm (Weinheim) 331: 249-253.

2. Wahe $H$, Asobo PF, Cherkasov RA, Nkengfack $A E$, Folefoc $G N$, et al. (2003) Heterocycles of biological importance. Part $6^{1}$. The formation of novel biologically active pyrimido [1,2-a] benzimidazoles from electron deficient alkynes and 2-aminobenzimidazoles. Arkivoc : 170-177.

3. Mor M, Bordi F, Silva C, Rivara S, Zuliani V, et al. (2004) Synthesis, biological activity, QSAR and QSPR study of 2-aminobenzimidazole derivatives as potent $\mathrm{H}_{3}$-antagonists. Bioorg Med Chem 12: 663-674.

4. de Dios A, Shih C, López de Uralde B, Sánchez C, del Prado M, et al. (2005)
Design of potent and selective 2-aminobenzimidazole-based p38alpha MAP kinase inhibitors with excellent in vivo efficacy. J Med Chem 48: 2270-2273.

5. Dayam R, Deng J, Neamati N (2006) HIV-1 integrase inhibitors: 2003-2004 update. Med Res Rev 26: 271-309.

6. Middleton J, Lim HB, Montgomery D, Rockway T, Tang H, et al. (2004) Inhibition of human immunodeficiency virus type I integrase by naphthamidines and 2-aminobenzimidazoles. Antiviral Res 64: 35-45.

7. Chassaing C, Berger M, Heckeroth A, Ilg T, Jaeger M, et al. (2008) Highly water-soluble prodrugs of anthelmintic benzimidazole carbamates: Synthesis pharmacodynamics, and pharmacokinetics. J Med Chem 51: 1111-1114.

8. Mpamhanga CP, Spinks D, Tulloch LB, Shanks EJ, Robinson DA, et al. (2009) One scaffold, three binding modes: novel and selective pteridine reductase 1 inhibitors derived from fragment hits discovered by virtual screening. $\mathrm{J}$ Med Chem 52: 4454-4465.

9. Bharti N, Shailendra, Gonzalez Garza MT, Cruz-Vega DE, Castro-Garza J, et al. (2002) Synthesis, characterization and antiamoebic activity of benzimidazole derivatives and their vanadium and molybdenum complexes. Bioorg Med Chem Lett 12: 869-871.

10. Ravina E, Sanches-Alonso R, Fueyo J, Baltar MP, Bos J, et al. (1993) Synthesis and potential anthelmintic activity of methyl-5-(4-salicyloyl-piperazin1-yl)-benzimidazole-2-carbamates. Arzneimittelforschung 43: 689-694.

11. Mavrova ATs, Denkova P, Tsenov YA, Anichina KK, Vutchev DI (2007) Synthesis and antitrichinellosis activity of some bis(benzimidazol-2-yl)amines. Bioorg Med Chem 15: 6291-6297.

12. Clément MJ, Rathinasamy K, Adjadj E, Toma F, Curmi PA, et al. (2008) Benomyl and colchicine synergistically inhibit cell proliferation and mitosis: evidence of distinct binding sites for these agents in tubulin. Biochemistry 47 : 13016-13025.

13. Yenjerla M, Cox C, Wilson L, Jordan MA (2009) Carbendazim inhibits cance cell proliferation by suppressing microtubule dynamics. J Pharmacol Exp Ther 328: 390-398.

14. Zhao Y, Pourgholami MH, Morris DL, Collins JG, Day Al (2010) Enhanced cytotoxicity of benzimidazole carbamate derivatives and solubilisation by encapsulation in cucurbit[ $n$ ] uril. Org Biomol Chem 8: 3328-3337.

15. Spagnuolo PA, Hu J, Hurren R, Wang X, Gronda M, et al. (2010) The antihelmintic flubendazole inhibits microtubule function through a mechanism distinct from vinca alkaloids and displays preclinical activity in leukemia and myeloma. Blood 115: 4824-4833.

16. Laryea D, Gullbo J, Isaksson A, LarssonR, Nygren P (2010) Characterization of the cytotoxic properties of the benzimidazole fungicides, benomyl and carbendazim, in human tumour cell lines and primary cultures of patient tumour cells. Anticancer drugs 21: 33-42.

17. Doudican N, Rodriguez A, Osman I, Orlow SJ (2008) Mebendazole induces apoptosis via $\mathrm{Bcl}-2$ inactivation in chemoresistant melanoma cells. Mol Cancer Res 6: 1308-1315.

18. Bai RY, Staedtke V, Aprhys CM, Gallia GL, Riggins GJ (2011) Antiparasitic 
Citation: Mavrova AT, Wesselinova D, Tsenov JA, Denkova P (2012) Cytotoxic Effects of Some N-Substituted-2-Amino-1H-Benzimidazoles. J Bioequiv Availab 4: 052-055. doi:10.4172/jbb.1000112

mebendazole shows survival benefit in 2 preclinical models of glioblastoma multiforme. Neuro Oncol 13: 974-982.

19. Mavrova ATs, Wesselinova D, Vassilev N, Tsenov JA (2011) Synthesis, characterization and cytotoxicity of some novel 1,3-disubstituted-2,3-dihydro2-iminobenzimidazoles. Eur J Med Chem 46: 3362-3367.

20. CellTiter $96{ }^{\circledR}$ Non-Radioactive Cell Proliferation Assay, Technical Bulletin
\#TB112, Promega Corporation USA.

21. Berridge MV, Tan AS (1993) Characterization of the cellular reduction of 3-(4,5-dimethylthiazol-2-yl)-2,5-diphenyltetrazolium bromide (MTT): subcellularlocalization, substrate dependence, and involvement of mitochondrial electrontransport in MTTreduction. Arch Biochem Biophys 303: 474-482. 